2021 • Fall - Güz • Volume - Cilt: 12 • Issue - Sayı: 47

\title{
İndirim Günü Reklamı Yapan Markalara Yönelik Sinik Tutumlar
}

\author{
Merve ÇERÇİ, Marmara Üniversitesi, Reklamcılık ve Tanıtım Anabilim Dall, Dr., \\ merve.cerci@hotmail.com, (ID) 0000-0002-3638-5243
}

ÖZ

\begin{abstract}
Indirim yapmak, yapılan indirimleri hedef kitleye duyurmak için sıklıkla reklam yapmak kimi zaman markalarn beklentilerinin aksine müşterilerinde sinik tutum gibi olumsuz yönde duygulara yol açabilir. Markalar müşterileri tarafindan şu an için tercih sebebi olsalar bile bu durum uzun vadede marka boykotu, yıkıcı tüketici davranışları gibi sonuçlar doğurabilir. Bu çalışmanın amacı en çok indirim günü reklamı yaptığı düşünülen Trendyol ve Çiçek Sepeti markalarına yönelik tüketicilerin sinik tutumların ölçümlemektir. Ayrıca, tüketicilerin sinik tutumlarnnn; onların demografik özelliklerine, bu markalardan daha önce alısveriş yapıp yapmadıklarma ve reklamlarda vaat edildiği gibi ürünlerin indirimli olup olmadığına dair inanca göre farklllık gösterip göstermediğinin tespitidir. Araştırma için Bozoklu ve Ermeç (2020) tarafindan Türkçe'ye çevrilmiş Tüketici Sinizmi Ölçeği (TSÖ) kullanılmıştır. Hazırlanan anket ile veriler çevrimiçi toplanmıştır. Araştırmada 169 kişiden toplanan datanın incelenmesi sonucunda; katılımcılarm tamamı bu markaların müşterisi olsa da bu markalara yönelik sinik tutumlara sahip olduklarn tespit edilmiştir. Katıllmoların bu sinik tutumlarn onların cinsiyetlerine göre farklılık göstermektedir. Ayrıca katılımcıların sıklıkla indirim günleri reklamı yapan markalara yönelik sinik tutumları onların bu markalarm reklamlarında vaat ettikleri gibi ürünlerinin indirimli olup olmadığına dair inançlarına göre de farklılık göstermektedir.

Sinik tutum kavramı yerli alanyazında üzerine az çalışılmış bir konu olması nedeni ile bu çalışmanın kendisinden sonra gelen çalışmalara bir zemin oluşturması umulmaktadır.
\end{abstract}

\section{Anahtar : : iletişim, reklam, tüketici davranışları, sinik tutum, indirim günleri}

Kelimeler

\section{Cynical Attitudes Towards Brands that Advertise for Sale Days}

ABSTRACT

The fact that offering discounts by brands and advertising their discounts to the target audience can sometimes lead to negative feelings such as cynical attitudes in customers contrary to the expectations of their brands. Even if brands are preferred by their customers, for the time being, this may result in long-term results such as brand boycott and consumer subverting behavior. This study aims to measure the cynical attitudes of consumers towards Trendyol and Çiçek Sepeti brands, which are thought to make the most discount day advertisements. 
It is aimed at finding out whether the cynical attitudes of the customers differentiate concerning their demographic characteristics, to the existence of previous experience of shopping from these brands, and to their belief in the reliability of the advertisements regarding the discounts. For the research, the Consumer Cynicism Scale (TSÖ) translated into Turkish by Bozoklu and Ermeç (2020) was used. The data were collected online. As a result of the study (n=169); Although all of the participants are customers of these brands, it has been determined that they all have cynical attitudes towards these brands. These cynical attitudes of the participants differ according to their gender. The cynical attitudes of the participants towards the brands that frequently advertise discount days also differ according to their beliefs about whether their products are discounted or not, as promised in the advertisements of these brands. Since the concept of cynical attitude is an understudied subject in the domestic literature, it is hoped that this study will form a basis for subsequent studies.

\section{Keywords : : Communication, Advertising, Consumer Behavior, Cynical Attitude, Discount Days}

\section{EXTENDED ABSTRACT}

The most characteristic features of consumers with cynical attitudes are that they are consumers who have lost their faith and trust in the brand. These consumers believe that brands only care about their own interests, and therefore they are not related to the wants and needs of consumers (Dolen, Cremer, \& Ruyter, 2012). It can be questioned by the target audience how much discount they actually made by the brands that repeatedly appeal to their target audience with the promise of discounts. The basic assumptions of this study are that the brands that appeal to their consumers with the promise of constant discounts may cause a loss of confidence in their customers that they are really giving discounts. If this loss of trust persists, cynical attitudes towards these brands may occur. In this direction, the main purpose of the study is to measure the cynical attitudes of consumers towards Trendyol and Çiçek Sepeti, two brands that frequently advertise discounts. In addition, it is to determine whether the cynical attitudes of consumers towards this brand differ according to their age and gender. The other side objectives of the study are to determine whether the cynical attitudes of consumers towards these brands differ depending on whether they have shopped from these brands before and whether their products are discounted as promised in the advertisements of these brands. For the research, the Consumer Cynicism Scale (TSÖ) translated into Turkish by Bozoklu and Ermeç (2020) was used. The data were collected online with the prepared questionnaire. In the study, the data collected from 169 people were examined.

When we look at the demographics of the participants to working women respondents' rate $(64.5 \%, n=109)$ than male respondents $(35.5 \%, n=60)$ rather seems to be over. Although it was included in the questionnaire developed for the research, none of the participants in this study stated that they were 65 years or older. In addition, the majority of the participants, $62.7 \%(n=106)$ are between the ages of $18-34$. This ratio is valid for income, and the majority of 
the participants $(43.8 \%, \mathrm{n}=74)$ do not have a personal income. This is due to the fact that the majority of the participants are between the ages of undergraduate students $(65.1 \%, n=110)$ or recent graduates. In the design of the research, the participants were shown the commercials prepared for the discount days of Trendyol (YouTube, 2020) and Çiçek Sepeti (YouTube, 2021) brands, and in this way, the participants were tried to be reminded of the commercials of the discount days.

The most basic emotion experienced by consumers with cynical attitudes towards brands is the feeling of insecurity (Chu \& Chylinski, 2006; Güven, 2016). When the mean and standard deviation values of the consumer cynicism scale are examined, it is seen that the 3 questions with the highest value are directly related to the damaged sense of trust of consumers towards these brands, and these results are in parallel with other studies on the subject in the literature. Although all of the participants in the study shopped either from Trendyol brand $60.9 \%(n=103)$ or from Çiçek Sepeti brand $39.1 \%(n=66)$, only 14 participants $(8.3 \%)$ belive that made discounts as promised in the advertisements of these brands.

This situation shows that the majority of the participants are distrustful of the brand image that they try to gain a place in the minds of consumers through the advertisements of these brands (Holt , 2002). The first of the hypotheses developed for the purposes of the study was that the participants had cynical attitudes towards Trendyol and Çiçek Sepeti advertisements. This hypothesis (H0) was confirmed. Accordingly, although all of the participants are customers of these brands, they have cynical attitudes towards these brands. When the demographic variables, which are the sub-purposes of the study, and the cynical attitudes of consumers towards brands are examined; It has been determined that there is a statistically significant difference between the cynical attitudes of female and male consumers towards brands. This does not apply to the age variable. Accordingly, age for participants between the ages of 18-34 with 35-44 there are not a statistically significant difference between the cynical attitudes of towards brands. This is valid for participants who have shopped from these brands before. In other words, there are not a statistically significant difference between previously to be consumption experience of consumers from these brands and cynical attitudes of towards brands. Another result obtained in the research is that the cynical attitudes of the participants towards the brands that frequently advertise the sale days show a significant difference according to their beliefs about whether their products are discounted as promised in the advertisements of these brands. This result shows parallelism with the results of the studies conducted in the literature on the role of advertisements in shaping cynical attitudes (Pollay, 1986; Koslow, 2000).

This study can be repeated with different characteristics and with a larger sample. In addition, different brands can be selected instead of the brands in question. 
Existing studies in the literature show that consumer cynicism is an issue that has the most potential threat for brands. It is very important for brands that aim to increase the number of their loyal customers, which aim much more than profit, to be aware of the cynical attitudes created by their consumers, and to carry out an integrated communication activity to cope with these feelings. Although there are various studies in the domestic literature on the subject, the link established between advertising and consumer cynicism is new in this study.

\section{GİRIŞ}

Tüketiciler markalara yönelik kimi zaman sadakat, aşk gibi pozitif güçlü duygular hissederken, kimi zaman da sinik tutum, marka nefreti, marka boykotu, marka şüpheciliği gibi negatif yönlü güçlü tutumlar hissedebilirler. Bazen de tüketicilerin markalar ile duygusal ilişkileri oldukça yüzeysel, yapmacık ya da yalnızca ticari olabilir. 2004 yılında Wood tarafından hazırlanan rapor tüketicilerin markalara olan güvenlerinin son 30 yılda giderek azaldığını göstermektedir (Wood, 2004). Sinik tutumlara sahip tüketiciler en karakteristik özellikleri markaya dair inançlarını, güvenlerini kaybetmiş tüketiciler olmalarıdır. $\mathrm{Bu}$ tüketiciler markaların yalnızca kendi çıkarlarını gözettiklerine inanırlar. Bu nedenle de tüketicilerin istek ve ihtiyaçları ile özünde hiç ilgili olmadıkları inancını taşırlar (Wood, 2004); (Dolen, Cremer \& Ruyter, 2012, s. 310). Bu inanç reklamlar aracılığ ile de pekişebilir (Koslow, 2000). Reklamlar albenili dünyalarından tüketicilerine birtakım vaatlerde bulunurlar. Bu vaatler kimi zaman gerçekleşmesi mümkün olmayan vaatler de olabilmektedir. Dikkatleri üzerine çekmek, akılda kalıcı olmak ve tercih edilmek için yaratılan bu dünya ve abartılı vaatler kimi zaman tüketicilerde isteklerinin gerçekleşmediği hissi uyandırabilir. Bu durum tüketicilerin markaların dürüstlükten çok uzak olduğu inancını taşımalarına ve bu inanç nedeni ile de belirli markalardan özellikle kaçınmalarına böylece onlara karşı sinik tutumlar geliştirmelerine neden olabilir (Holt, 2002).

Ülkemizde farklı isimlerle anılan Black Friday, alışverişin adeta şölene dönüştürüldügü bir indirim günüdür. Bu indirim günü bazı markalar tarafından farklı isimlendirilerek farklı tarihlerde yıl boyu süren bir festivale dönüştürülmüştür. Sürekli indirim yapmak bu indirimlerin duyurulmasını gerekliliğini de beraberinde getirmektedir. Hedef kitlesine tekrarlayan bir şekilde indirim vaadi ile seslenen markaların, gerçekten ne kadar indirim yaptıkları hedef kitlesi tarafından sorgulanabilir hale gelebilmektedir. $\mathrm{Bu}$ çalışmanın temel varsayımları sürekli indirim vaadi ile tüketicilerine seslenen markaların gerçekten sürekli indirim yapıyor olduğu ile ilgili müşterilerinde güven kaybı yaşatabileceği bu güven kaybının sürekliliği halinde bu markalara yönelik sinik tutumlar oluşabileceğidir. $\mathrm{Bu}$ doğrultuda, bu çalışmanın amacı en çok indirim reklamı yaptığı saptanan Trendyol ve Çiçek Sepeti markalarına yönelik sinik tutumları ölçümlemektir. Sinizm kavramı alanyazında 
oldukça yeni bir kavram olması nedeni ile kavram üzerine bu ve benzeri çalışmalar yapılmasının alana katkı sağlayacağına inanılmaktadır.

\section{TEORIKK ARKAPLAN}

\section{1.İndirim Günleri}

Black Friday Kasım ayının dördüncü cuması olan (26 Kasım), Hristiyan inancına sahip kişiler tarafından kutlanan Şükran gününden (25 Kasım) bir gün sonrasına denk gelen bir gündür. Tarihten de de anlaşılacağı üzere tek bir gün olması gereken bu indirim günü, önce Perşembe ve takibindeki 3 günü de içine alarak büyümüş, sonrasında ise muhteşem aralık, şahane ocak şeklinde genişlemiştir. Black Friday adı altındaki indirim günleri ile satışlarını arttıran işletmeler bu günlere kendi belirledikleri isimler ve tarihler ile peş peşe yenilerini eklemiştir. Böylece alışveriş yapmanın kendisi her an kutlanması gereken bir şölene dönüştürülmüştür. Kendi belirlediği isimler ve tarihler ile seri indirim günleri yapan şirketlerden biri Trendyol'dur. Trendyol 2010 yılında kurulan bir e-ticaret şirketidir. Bugün geldiği noktada Trendyol Tech, Trendyol Express, Market ve Yemek hızlı teslimat hizmeti veren Trendyol Go ve ikinci el ürün platformu Dolap gibi alt markaları da bünyesinde barındırmaktadır (Trendyol, 2021).

Trendyol, kendi ismini verdiği "Trendyol Efsane İndirim Günleri” adı altında indirimler yaparak bu indirim günlerini reklamlar aracılığı ile hedef kitlesine duyurmaktadır. Markanın yalnızca 2020 yılının Kasım ayında düzenlediği kampanyalar ile 1,5 milyar ziyaretçiye, 25 milyon aktif kullanıcıya ulaştığ gerçekleştirdiği bilinmektedir (Özbek, 2021). Trendyol Black Friday indirimlerinden önce, indirim kampanyalarına Eylül 2020 tarihinde "Mega Eylül" kampanyası ile başlamıştır. Sonrasında, Black Friday'ın Çin'de kutlanan versiyonu olan 11.11 indirimi için 9-12 Kasım 2020 tarihlerinde 3 gün süren bir indirim kampanyası ardından 26-30 Kasım 2020 tarihleri arasında "Efsane Günler" ismi ile Black Friday indirimini başlatmıştır. Sonrasında, 21 Aralık'ta 2020'de “En Uzun Gece İndirimi”, 27-31 Aralık 2020 yine “Efsane Günler" isimli yeni bir indirim kampanyası ve Ocak 2021'den tarihinden itibaren ise her ay yeni bir indirim kampanyası düzenlemiştir. Bu kampanyalar bazen 12 Şubat 2021 tarihinde olduğu gibi "Sevgililer Günü İndirimi” şeklinde özel günlere yönelik olabileceği gibi 15-19 Nisan 2021 "Kozmetik Günleri” ya da 16-17 Haziran 2021 “Mobilya Günleri” indirimlerinde olduğu gibi ürün bazlı da olabilmektedir. Trendyol tüm bu indirim günlerini hem televizyon reklamları hem de internet reklamları aracılığı ile hedef kitlesine duyurmuş ayrıca birçok etkili kişi ile çalışmıştır.

Bir diğer seri indirim günleri düzenleyen şirket ise Çiçek Sepeti'dir. Çiçek Sepeti 2006 yılında kurulan bir e- ticaret sitesidir. Şirket kurulduğu ilk yıllarda yalnızca çiçek satışı yapsa da bugün çiçek ve yenilebilir çiçek kategorilerinin yanı sıra bünyesine kattığı elektronik, ev \& 
yaşam, kişisel bakım, süpermarket, kozmetik, moda, spor \& outdoor, hobi, pet shop ve takı \& aksesuar gibi farklı kategorilere de sahiptir (Çiçek Sepeti, 2021). Çiçek Sepeti de aynı amaçlar doğrultusunda kendi adını verdiği bir indirim günleri serisi başlatarak bu indirim günlerini "Çiçek Sepeti Var Var İndirimleri" olarak adlandırmıştır. Çiçek Sepeti, Black Friday öncesinde 8-9-10 Eylül 2020 tarihlerinde başlattığı indirimlerini tıpkı Trendyol gibi neredeyse her ay yenilemiştir. Bunlar: 9-10-11-12 Kasım 2020 “Var Var İndirimleri”, 12-13-14 Ocak 2021 "Var Var İndirimleri", 1-5 Şubat “Var Var İndirimleri”, 2-3-4- Mart “Var Var İndirimleri”, 6-8 Nisan 2021 “Var Var İndirimleri”, 2-3-4 Haziran 2021 “Var Var İndirimleri” şeklindedir. "Var Var İndirimleri” dışında Çiçek Sepeti “Ramazan Özel”, “Dünya Kadınlar Gününe Özel”, anneler, babalar, öğretmenler, sevgililer günlerine ve de en uzun geceye özel indirim kampanyaları da düzenlenmiştir. Marka Black Friday indirimlerini 29 Kasım 2020'de "Büyük Cuma" ismi ile gerçekleştirmiştir. Ayrıca 12.12.2020 tarihinde "12.12" isimli bir indirim kampanyası da yapmıştır. Bu indirim günlerine ek olarak Trendyol markasında olduğu gibi 20 Mayıs 2021'de “Kozmetik ve Kişisel Bakım Festivali", 25 Mayıs 2021'de “Büyük Market Günleri”, 8 Haziran 2021'de ise "Elektronik Ürünlerde İndirim" kampanyaları da düzenlemiş ve tüm bu indirimlerin tamamın hedef kitlesine duyurmak için hem televizyon hem de internet reklamlarını kullanmıştır.

\subsection{Sinik Tutum Kavramı}

Tutum biliş, duygu ve davranışı içinde barındıran çok yönlü bir kavramdır. Tutumlar kişilerin sabit kısa yollarıdır ve bu halleri ile davranışlarının yordayıcısı görevi görmektedir (Taylor, Peplau, \& Sears, 2010, s. 140). Sinik tutum pasifize bir durum olup tutum sözcüğü ile karşılansa bile duygu ve biliş boyutu ağırlıkta olup davranış boyutu oldukça sınırlıdır. Davranış boyutu ağır basan tüketici aktivitelerine ise; yıkıcı reklamlar, boykotlar, kültür bozumu, etik tüketici davranışları örnek gösterilebilir (Helm, Moulard, \& Richins, 2015, s. 517). Sinik tüketiciler yozlaşmış sistemi değiştirmekten ziyade, pasifize olarak iç huzursuzluklarını hafifletmeye çalışırlar (Brenton, 2013). Bir anlamda duygusal olarak dengede kalmaya çalışırlar. Bu dengeyi de davranış duygu ve bilgi düzeyinde gerçekleştirirler.

Satın aldıkları mal ve hizmetler ile kendilerini anlatmaya çabalayan bugünün tüketicileri, satın aldıkları ürünler aracılığı ile birçok duygulanım yaşamaktadırlar. Bu kimi zaman mutluluk kimi zaman sevinç gibi olumlu anlamlar yüklenen duygular iken kimi zaman da güvensizlik, tatminsizlik gibi olumsuz anlamlar yüklenen duygular olabilmektedir. Müşterilerin markalara karşı yaşadığı sevgi ve bağlılık içeren duygular alanyazında marka aşkı, marka sadakati gibi kavramların başlığı altında tartışılırken, müşterilerin yaşadığı güven kaybı, tatminsizlik gibi duygular sinizm kavramı adı altında çalışılmaktadır. Kişilerin bireysel olarak hissettikleri bir duygu olan sinizmi, tüketicilerin satın aldıkları ürünler ile bir bağ kurmaları nedeni ile tüketici davranışları perspektifinden de üzerine çalışılabilen bir konu haline gelmiştir (Devlin \& McKechnie, 2008). Tüketici sinizmin üzerinde uzlaşılan bir tanımı 
bulunmamaktadır. Bu nedenle, kavram farklı araştırmacılar tarafından farklı boyutları ele alınarak tanımlanmıştır. Chu ve Chylinski (2006) sinizmi güvensizlik, tatminsizlik ve karşılanmamış beklentiler ile ilişkilendirmiştir. Andersson ve Bateman (1997) ise sinizm öğrenilmiş bir tutum olduğunu ve beklentilerin sürekli bir şekilde engellenmesi tatmin edilmemesinden kaynaklandığı iddia etmektedir. Yapılan çalışmalar sinizm temelinde karşılanmayan beklentiler sonrasında ortaya çıkan güven kaybının yer aldığı göstermektedir (Güven, 2016, s. 155). Bu güven kaybı markanın tüm unsurlarına sirayet ederek, markanın tüketici zihninde sahip olmaya çalıştığı tüm eşsiz otantik biriciklik algısına karşı da güvensizliğe sebep olmaktadır (Holt, 2002).

Alanyazında konu özelinde yapılan çalışmalar sinik tutumların şekillenmesinde reklamların rolünü ortaya çıkarmaktadır (Pollay, 1986; Koslow, 2000). Reklamlar ister toplumu değiştiren bir unsur ister toplum tarafından şekillenen bir unsur olsun, gerçek şu ki reklamlar aracılığı ile markalar müşterilerine vaatlerini iletirler. Bu vaatler kimi zaman oldukça gerçekçi rasyonel olabilirken, kimi zaman da gerçekleşmesi pek mümkün olmayan vaatler de olabilmektedir. Reklamlar aracılığı ile iletilen vaatler doğrultusunda beklentiye giren tüketicilerin bu beklentilerin ne ölçüde karşılandığı ya da karşılanmadığı onların sinik tutumların nedeni olabilmektedir (Koslow, 2000). Reklamların yanı sıra, marka ile müşteri arasındaki etik uyuşmazlıklar da zamanla sinik tutumlara neden olabilmektedir (Chu \& Chylinski, 2006). Bugünün tüketicileri tercih ettikleri ya da etmek isteyecekleri markalardan doğaya, hayvanlara kısacası yaşama saygılı olmalarını beklemektedir. Böyle bir beklenti içinde olan müşteriler için tüketicisi olduğu bir kozmetik markasının hayvanlar üzerinde deneyler yaptığını, ya da tüketicisi olduğu bir markanın çocuk işçiler çalıştırdığını bilmek tüketicilerin o markaya yönelik sinik tutumlar geliştirmesine neden olabilir.

\section{YÖNTEM}

$\mathrm{Bu}$ çalışmanın amacı, sıklıkla indirim günleri yapan markalara yönelik tüketicilerin sinik tutumlarını ölçümlemektir. Çalışmanın yan amaçları ise tüketicilerin sinik tutumlarının; onların demografik özelliklerine göre, bu markalardan daha önce alışveriş yapıp yapmadığına göre ve de reklamlarda vaat edildiği gibi ürünlerin indirimli olup olmadığına dair inancına göre farkl1lık gösterip göstermediğinin tespit etmektir. Bu amaç ve yan amaçlar doğrultusunda çalışma için bir anket geliştirilmiştir. Ankette yer alan ölçek Helm, Moulard ve Richins (2015) tarafından geliştirilmiş ve 2020 yılında Bozoklu ve Ermeç (2020) tarafından Türkçe'ye çevrilmiştir. Çalışmada 8 ifadeden oluşan “Tüketici Sinizmi Ölçeği'nin” (TSÖ) yanı sıra 7 farklı soru yer almaktadır. Bu sorulardan 4 tanesi tüketicilerin demografik özelliklerini saptamaya yöneliktir. Diğer 3 soru ise çalışmanın yan amaçlarını saptamak amacı ile sorulmuştur. Çalışmanın örneklemini 18-65 yaş arasındaki Türkiye'de yaşayan ve internet kullanan tüketiciler oluşturmaktadır. Çalışmanın temel kısıtlarından olan zaman ve maliyet 
kısıtlaması nedeni ile yöntem olarak kolayda örnekleme yöntemi seçilmiştir. Ayrıca araştırmanın yapıldığı dönemlerde pandemi koşulları nedeni ile anket çevrim içi yöntem ile toplanmıştır. Anket formunun dizaynı katılımcıların önce reklam filmlerini izlemesi sonrasında da soruları cevaplaması şeklinde yapılmıştır. Bunun temel nedeni katılımcılara araştırma için seçilen Trendyol ve Çiçek Sepeti'nin indirim reklamlarından birer örnek göstererek onlara bu reklamları hatırlatmaktır. Sonrasında da katılımcıların bu iki markaya yönelik sinik tutumları ölçümlenmiştir. Araştırma için Trendyol ve Çiçek Sepeti markalarının seçimi de yine anket yöntemi ile gerçekleşmiştir. Bu tespit için 1 Mayıs 2021- 1 Haziran 2021 tarihleri arasında Google Formlar aracılığı ile 567 katılımcıya en çok indirim reklamlarını gördükleri markaların hangileri olduğu sorulmuş ve en çok indirim reklamı yaptığı tespit edilen Trendyol ve Çiçek Sepeti markaları araştırmaya dahil edilmiştir. Katılımcılara indirim reklamlarını hatırlatmak amacı ile izletilen 2 reklam filmi de markaların resmi YouTube sayfalarında en çok etkileşim alan reklam filmleri olan Trendyol Efsane İndirim Günleri (YouTube, YouTube, 2020) ve Çiçek Sepeti Var Var İndirimleri (YouTube, YouTube, 2021) reklamlarıdır.

Bu araştırma için (Holt, 2002); (Güven, 2016); (Helm, Moulard, \& Richins, 2015)'in çalışmalarından yola çıkılarak aşağıda yer alan hipotezler geliştirilmiştir:

$H^{0}$ : Katılımcıların sıklıkla indirim günleri reklamı yapan markalara yönelik sinik tutumları mevcuttur.

$H^{1}$ : Katılımcıları sıklıkla indirim günleri reklamı yapan markalara yönelik sinik tutumları onların cinsiyetlerine göre anlamlı bir farklılık göstermektedir.

$H^{2}$ : Katılımcılarm sıklikla indirim günleri reklamı yapan markalara yönelik sinik tutumları onların yaşlarına göre anlamlı bir farklılık göstermektedir.

$H^{3}$ : Katılımcıların sıklkkla indirim günleri reklamı yapan markalara yönelik sinik tutumları onların bu markalardan daha önce alışveriş yapıp yapmadı̆̆ına göre anlamlı bir farklılık göstermektedir.

$H^{4}$ : Katılımcıların sıklikla indirim günleri reklamı yapan markalara yönelik sinik tutumları onların bu markaların reklamlarmda vaat ettikleri gibi ürünlerinin indirimli olup olmadiğıına dair inançlarına göre anlamlı bir farklılık göstermektedir.

$\mathrm{Bu}$ araştırmanın kısıtlılıkları, farklı demografik özelliklere sahip (yaş, gelir, eğitim) katılımcılar ve daha geniş örneklem ile ortadan kalkabilir. Çalışma için, 5 Mart 2021- 1 Haziran 2021 tarihleri arasında erişime açı kalan platformdan, toplamda 172 anket elde edilmiştir. Anketler incelenerek hatalı, eksik ya da tutarlı olanları ayıklandıktan sonra kullanılabilir anket sayısı 169'a düşmüştür. Çalışmanın türü tanımsal bir araştırma olup, veriler SPSS 26.0 paket programı kullanılarak analize tabi tutulmuştur. 


\subsection{Bulgular}

Araştırmaya katılan 169 kişiye ait demografik bilgiler aşağıda bulunan Tablo1'de yer almaktadır. Tablo 1'e göre katılımcıların \%64,5'ü (n=109) kadın, \%35,5'i (n=60) erkektir. Bu durum kadın katılımcların oranının (\%64,5, n=109) erkek katılımcılara göre $(\% 35,5, n=60)$ oldukça fazla olduğunu göstermektedir. Yaş dağılımına bakıldığında ise \%62,7'si 18-34 yaş (n=106), \%34,3'nün 34-44 yaş $(n=58)$ ve \%3'nün 45-64 yaş $(n=5)$ aralı̆̆ında olduğu görülmektedir. Anket formunda yer almasına karşın hiçbir katılımcı 65 yaş ve üstü yaşta olduğunu belirtmemiştir. Bunun yanı sıra katılımcıların büyük çoğunluğu \%62,7'si (n=106) 1834 yaş arasında yer almaktadır. Katılımcıların gelirlerine bakıldı ̆̆ında ise, \%43,8' in (n=74) kişisel bir gelire sahip olmadığı, \%8,9'nun (n=15) 1.000 TL'den az gelire sahip olduğu, \%5,3'nün (n=9) 1.001 TL- 5.000 TL arasında gelire, \%15,4'nün (n=26) 5.001 TL- 10.000 TL arasında, \%26,6'sının $(\mathrm{n}=45)$ 10.001 TL ve üzeri bir gelire sahiptir. Bunların yanı sıra katılımcıların eğitim düzeylerine bakıldığında \%16,6'sının ( $=28)$ lise, \%65,1'nin (n=110) lisans ve \%18,3’nün (n=31) lisansüstü mezunu olduğu görülmektedir. Katılımcıların çoğunluğunun yaşlarının lisans öğrencisi $(\% 65,1, n=110)$ ya da yeni mezun olabilecek yaşlar arasında olması katılımcıların \%43,8'ün (n=74) neden kişisel bir gelire sahip olmadığı ile ilgili açılama olabilecek niteliktedir.

Tablo 1: Demografik değişkenler

\begin{tabular}{clcc}
\hline $\begin{array}{c}\text { Değişke } \\
n\end{array}$ & Dïzey & $N$ & $\%$ \\
\hline \multirow{2}{*}{ Cinsiyet } & Kadın & 109 & $\% 64,5$ \\
& Erkek & 60 & $\% 35,5$ \\
\hline \multirow{3}{*}{ Yaş } & $18-34$ & 106 & $\% 62,7$ \\
& $35-44$ & 58 & $\% 34,3$ \\
& $45-64$ & 5 & $\% 3$ \\
\hline \multirow{4}{*}{ Gelir } & Kişisel gelirim yok & 74 & $\% 43,8$ \\
& 1000TL'den az & 15 & $\% 8,9$ \\
& 1.001 TL-5.000 TL & 9 & $\% 5,3$ \\
& $5.001 T L-10.000$ TL & 26 & $\% 15,4$ \\
& 10.001 TL ve üzeri & 45 & $\% 26,6$ \\
\hline \multirow{3}{*}{ Eğitim } & Lise & 28 & $\% 16,6$ \\
& Lisans & 110 & $\% 65,1$ \\
& Lisansüstü & 31 & $\% 18,3$ \\
\hline Toplam & & $\mathbf{1 6 9}$ & $\mathbf{0 1 0 0}$ \\
\hline
\end{tabular}

Demografik özelliklerin yanı sıra katılımcılara daha önce Trendyol ya da Çiçek Sepeti mağazalarından alışveriş yapıp yapmadıkları sorulmuş araştırmaya katılanların \%69,8'i $(n=118)$ bu soruya evet cevabını verirken \%30,2'si (n=51) hayır cevabını vermiştir. Katılımcıların \%60,9'nu (n=103) Trendyol'dan \%39,1 ise (n=66) Çiçek Sepeti'nden alışveriş yapmıştır. Ayrıca katılımcılara bu markaların reklamlarında vaat ettikleri gibi indirim 
yaptıklarına inanıyor musun diye de sorulmuştur. \%8,3 oranla 14 katılımcı bu soruya evet cevabını verirken \%91,7 oranla 155 katılımcı bu soruya hayır cevabını vermiştir.

Tüketici Sinizimi Ölçeği'nin ortalama ve standart sapma değerleri bakıldığında ise en yüksek değere sahip 3 soru başka bir deyişle katılımcıların en çok katıldıkları ifadeler; "Bu markalar kar elde edebilmek için ellerinden geleni yapma isteği duymaktadırlar." (4,45), "Eğer paramın karşılığını almadığımı düşünüyorsam, bu markaların bana söylediklerine inanmam." $(4,22)$ ve "Bu markalar kâr marjını iyileştirmek için ellerinden geleni ardına koymamaktadır." $(4,15)$ olmuştur.

Çalışmada kullanılan Tüketici Sinizmi Ölçeğinin Cronbach Alfa değeri.816'dır. Bu analiz bir ölçek içinde bulunan tüm değişkenlerin aynı kavramı ölçmekte ne kadar başarı olduğu göstermektedir. Bu değerin 0,81 ve üzeri bir değerde olması ölçeğin yüksek iç tutarlılığa sahip olduğunu ayrıca oldukça güvenilir olduğunu göstermektedir (Nunnally, 1978).

\subsection{Hipotezlerin Test Edilmesi}

$H^{0}$ : Katılımcıların sıklıkla indirim günleri reklamı yapan markalara yönelik sinik tutumları mevcuttur.

Hipotezini test etmek üzere araştırmada Tek örneklem T testi yapılmıştır. Bu test sinik tutum ölçeğine ait sorulara verilen cevapların 3 değerinden ( 3 değeri=bazen) büyük olup olmadığını sınamaya yönelik bir testtir. Tüketici sinizmi ait verilen cevapların ortalamalarının 3 değerinden daha fazla olması tüketicilerin araştırmaya dahil edilen 2 markaya yönelik sinik tutumlara sahip olduğunu göstermektedir.

Tablo 2: Tek örneklem T- Testi

\begin{tabular}{lccccc}
\hline & $n$ & $\begin{array}{c}\text { Mea } \\
n\end{array}$ & $S d$ & $t$ & $p$ \\
\hline Sinik tutum ortalama & 169 & 3.92 & .599 & 20.48 & .000 \\
\hline
\end{tabular}

Tablo 2'de yer alan sonuçlara göre, katılımcı gruba ait sinik tutum cevapları ile popülasyon ortalaması tek örneklem $t$ testi ile karşılaştırıldı̆̆ında, grubun sahip olduğu sinik tutum ortalaması $(\mathrm{M}=3.92, \mathrm{SD}=.599)$, popülasyona ait ortalama ise $(\mu=3)$ istatiksel olarak anlamlıdır, [t $(168)=20.648,0.00<0.05]$. Bu haliyle $\mathrm{H}^{0}$ kabul edilmiştir.

$H^{1}$ : Katılımcıların sıklıkla indirim günleri reklamı yapan markalara yönelik sinik tutumları onların cinsiyetlerine göre anlamlı bir farklılık göstermektedir. 


\section{AJIT-e Bilişim Teknolojileri Online Dergisi \\ Academic Journal of Information Tecnology \\ 2021 Fall/Güz - Cilt/Vol: 12 - Sayı/Issue: 47 \\ 10.5824/ajite.2021.04.002.x}

Katılımcıların sıklıkla indirim günleri reklamı yapan markalara yönelik sinik tutumları onların cinsiyetlerine göre anlamlı bir farklılık gösteriyor mu saptanmak için tek yönlü varyans analizi yapılmıştır. Yapılan test sonuçları Tablo 3'te yer almaktadır. Test sonuçlarına göre, p değerinin 0.005 anlamlılık düzeyinin altında olması nedeni ile [t $(167)=2.669,0.005$ $<0.05$ ] cinsiyet grupları ile sinik tutumları arasında istatiksel olarak anlamlı bir fark olduğu saptanmıştır. $\mathrm{H}^{1}$ kabul edilmiştir.

Tablo 3: Cinsiyet- T- Testi

\begin{tabular}{ccccccc}
\hline Puanlar & Değişken & $\boldsymbol{n}$ & $\boldsymbol{A O}$ & $\boldsymbol{S d}$ & $\boldsymbol{t}$ & $\boldsymbol{p}$ \\
\hline & 1. Kadın & 109 & 3.83 & .62 & 2.66 & .005 \\
& 2. Erkek & 60 & 4.08 & .51 & 2.83 &
\end{tabular}

$H^{2}$ : Katılımcıların sıklıkla indirim günleri reklamı yapan markalara yönelik sinik tutumları onların yaşlarına göre anlamlı bir farklılık göstermektedir.

Katılımcıların sıklıkla indirim günleri reklamı yapan markalara yönelik sinik tutumları onların yaşlarına göre anlamlı bir farklılık gösteriyor mu saptanmak için tek yönlü varyans analizi yapılmıştır. Demografik bir özellik olan yaş değişkeni içinde de yer alan bazı grupların 30 birimden az olması nedeni ile grupların gözlem sayılarının birbirleri ile yakınlaştırılması gerekmiş, bu amaç doğrultusunda 35-44 ve 45-64 yaş grupları 35-64 şeklinde tek bir grup haline getirilmiştir. Diğer grup ise Tablo 1'de belirtildiği hali ile kalmıştır. Böylece toplamda iki farklı yaş grubu oluşturulmuştur. Yapılan test sonuçları Tablo 4'te yer almaktadır. Test sonuçlarına göre, p değerinin 0.005 anlamlılık düzeyinin üstünde olması nedeni ile [t (167) $=1.465,0.141>0.05$ ] yaş grupları ile sinik tutumları arasında istatiksel olarak anlamlı bir fark olmadığı saptanmıştır. $\mathrm{H}^{2}$ reddedilmiştir.

Tablo 4: Yaş T- Testi

\begin{tabular}{llccccc}
\hline Puanlar & Değişken & $\boldsymbol{n}$ & $\boldsymbol{A O}$ & $\boldsymbol{S d}$ & $\boldsymbol{t}$ & $\boldsymbol{p}$ \\
\hline & $1.18-34$ & 106 & 3.87 & .60 & 1.45 & \\
& $2.35-64$ & 63 & 4.01 & .58 & 1.47 & .141
\end{tabular}


Katılımcıların demografik özelliklerine göre hipotezler test edilirken gelir ve eğitim durumu test edilmemiştir. Bunun temel nedeni ise Tablo 1'de yer alan dağılımlardır. Tabloya göre demografik bir özellik olan eğitim ve gelir değişkeni içinde de yer alan bazı grupların 30 birimden az olması nedeni bu iki demografik özelliklere göre test edilmemiştir.

$H^{3}$ : Katılımcıların sıklıkla indirim günleri reklamı yapan markalara yönelik sinik tutumlar onların bu markalardan daha önce alışveriş yapıp yapmadı̆̆ına göre anlamlı bir farklılık göstermektedir.

Katılımcıların sıklıkla indirim günleri reklamı yapan markalara yönelik sinik tutumları onların bu markalardan alışveriş yapıp yapmadığına göre anlamlı bir farklılık gösteriyor mu saptanmak için tek yönlü varyans analizi yapılmıştır. Yapılan test sonuçları Tablo 5 'te yer almaktadır. Test sonuçlarına göre, p değerinin 0.005 anlamlılık düzeyinin üstünde olması nedeni ile $[\mathrm{t}(167)=.515,0.610>0.05]$ yaş grupları ile sinik tutumları arasında istatiksel olarak anlamlı bir fark olmadığı saptanmıştır. $\mathrm{H}^{3}$ ret edilmiştir.

Tablo 5: Alışveriş Deneyimi T- Testi

\begin{tabular}{llccccc}
\hline Puanlar & Değişken & $\boldsymbol{n}$ & $\boldsymbol{A O}$ & $\boldsymbol{S d}$ & $\boldsymbol{t}$ & $\boldsymbol{p}$ \\
\hline & 1. Evet & 118 & 3.91 & .59 & .515 & \\
& 2. Hayır & 51 & 3.96 & .60 & .512 & .610 \\
\hline
\end{tabular}

$H^{4}$ : Katılımcıların sıklıkla indirim günleri reklamı yapan markalara yönelik sinik tutumları onların bu markaların reklamlarında vaat ettikleri gibi ürünlerinin indirimli olup olmadığına dair inançlarına göre anlamlı bir farklılık göstermektedir.

Katılımcıların sıklıkla indirim günleri reklamı yapan markalara yönelik sinik tutumları onların bu markaların reklamlarında vaat ettikleri gibi ürünlerinin indirimli olup olmadığına dair inançlarına göre anlamlı bir farklılık gösteriyor mu saptanmak için tek yönlü varyans analizi yapılmıştır. Yapılan test sonuçları Tablo 5'te yer almaktadır. Test sonuçlarına göre, $\mathrm{p}$ değerinin 0.005 anlamlılık düzeyinin altında olması nedeni ile [t $(167)=3.20,0.010<0.05$ ] cinsiyet grupları ile sinik tutumları arasında istatiksel olarak anlamlı bir fark olduğu saptanmıştır. $\mathrm{H}^{4}$ kabul edilmiştir.

Tablo 6: İndirim Vaadine Dair İnanç T- Testi

\begin{tabular}{llccccc}
\hline Puanlar & Değişken & $\boldsymbol{n}$ & $\boldsymbol{A O}$ & $\boldsymbol{S d}$ & $\boldsymbol{t}$ & $\boldsymbol{p}$ \\
\hline 1. Evet & 14 & 3.45 & .63 & 3.20 & \\
& 2. Hayır & 155 & 3.97 & .57 & 2.94 & .010 \\
\hline
\end{tabular}




\section{AJIT-e Bilişim Teknolojileri Online Dergisi \\ Academic Journal of Information Tecnology \\ 2021 Fall/Güz - Cilt/Vol: 12 - Sayı/Issue: 47 \\ doi) 10.5824/ajite.2021.04.002.x}

Tüketicilerin indirim reklamı yapan markalara yönelik sinik tutumların ölçümlendiği bu çalışmada bu amaç doğrultusunda geliştirilen $\mathrm{H}^{0}, \mathrm{H}^{1}, \mathrm{H}^{4}$ kabul edilirken $\mathrm{H}^{2}$ ve $\mathrm{H}^{3}$ reddedilmiştir.

\section{TARTIŞMA VE SONUÇ}

Bu çalışmanın temel amacı sıklıkla indirim reklamı yapan iki marka olan Trendyol ve Çiçek Sepeti'ne yönelik tüketicilerinin sinik tutumlarını ölçümlemektir. Bunun yanı sıra, tüketicilerin bu markaya yönelik sinik tutumların onların yaşlarına ve cinsiyetlerine göre farklılık gösterip göstermediğinin saptanmasıdır. Çalışmanın diğer yan amaçları ise, tüketicilerin bu markalara yönelik sinik tutumlarının onların bu markalardan daha önce alışveriş yapıp yapmadığına ve de bu markaların reklamlarında vaat ettiği gibi ürünlerinin indirimli olup olmadığına dair tüketicilerinin taşıdığ1 inanca göre farklılık gösterip göstermediğinin de belirlenmesidir. Yukarıda belirtilen amaçlar doğrultusunda gerçekleştirilen araştırmanın dizaynında katılımcılara Trendyol (YouTube, YouTube, 2020) ve Çiçek Sepeti (YouTube, YouTube, 2021) markalarına ait indirim günleri için hazırlanmış reklam filmleri izlettirilmiş bu yol ile katılımcılara indirim günlerine ait reklam filmlerinin neler olduğu hatırlatılmaya çalışılmıştır. Reklam filmlerinin ardından katılımcılardan ölçümleme alınmıştır.

Alan yazındaki çalışmalar markalara yönelik sinik tutumlara sahip tüketicilerin en temel yaşadığı duygu güvensizlik duygusu olduğuna işaret etmektedir (Chu \& Chylinski, 2006; Güven, 2016). Çalışmada yer alan tüketici sinizmi ölçeğinin ortalama ve standart sapma değerleri bakıldığında en yüksek değere sahip 3 sorunun tüketicilerin bu markalara yönelik zedelenen güven duygusu ile doğrudan ilintili olduğu ve bu hali ile sonuçların alan yazında yer alan konu özelindeki diğer çalışmalar ile paralellik gösterdiği görülmektedir.

Yapılan araştırma sonucunda katılımcıların tamamı ya Trendyol markasından \%60,9 ( $\mathrm{n}=103)$ ya da Çiçek Sepeti markasından \%39,1 (n=66) alışveriş yapmasına rağmen yalnızca 14 katılımcının $(\% 8,3)$ bu markaların reklamlarında vaat ettikleri gibi indirim yaptıklarına inandığı saptanmıştır. Bu durum katılımcıların büyük çoğunluğunda bu markaların reklamları aracılığı ile tüketicilerin zihninde yer edinmeye çalıştıkları marka imaja karşı güveniz olduğu göstermektedir (Holt, 2002).

Çalışmada katılımcıların Trendyol ve Çiçek Sepeti reklamlarına yönelik sinik tutumları incelendiğinde; katılımcıların bu markalara yönelik sinik tutumlara sahip olduğu tespit edilmiştir. Ayrıca yapılan araştırmalar sonucu kadın ve erkek tüketicilerin markalara yönelik sinik tutumları arasında istatiksel olarak anlamlı bir fark olduğu saptanmıştır. Bu farklılık kadın ve erkeklerin alışveriş alışkanlıklarının farklı olmasından, kadınların alıverişlerinde 
kozmetik ve giyim gibi kalemleri tercih ederken erkeklerin yoğunlukla teknolojik ürünler almasından kaynaklandığı düşünülmektedir.

Çalışmanın biri diğer sonucu ise tüketicilerin araştırma konusu olan bu 2 markadan alışveriş yapmış ya da alışveriş yapmamış olmalarına başka bir ifade ile bu markalar ile tüketim deneyimi yaşamış ya da yaşamamış olmalarının bu markalara yönelik sinik tutumları arasında istatiksel olarak anlamlı bir fark bulunmamış olmasıdır. Bu sonuç tüketicilerin marka ile bir deneyim yaşamasından bağımsız bir şekilde onlara yönelik sinik tutum geliştirebileceklerini göstermektedir.

Yapılan araştırma sonuçlarında katılımcların sıklıkla indirim günleri reklamı yapan markalara yönelik sinik tutumları onların bu markaların reklamlarında vaat ettikleri gibi ürünlerinin indirimli olup olmadığına dair inançlarına göre anlamlı bir farklılık gösteriyor olduğudur. Bu sonuç alanyazında konu özelinde yapılan çalışmalar sinik tutumların şekillenmesinde reklamların rolünün (Pollay, 1986; Koslow, 2000) olduğu sonucu ile paralellik göstermektedir.

Bu çalışma farklı özelliklerde ve daha geniş bir örneklem ile tekrarlanabilir. Ayrıca araştırmaya söz konusu olan markalar yerine farklı markalar da seçilebilir.

Alan yazında var olan çalışmalar tüketici sinizmin markalar için dikkate alınması gereken potansiyel bir tehdit barındıran bir konu olduğunu göstermektedir. Kar etmekten çok daha fazlasını hedefleyen, sadık müşterilerinin sayısını arttırmayı amaçlayan markalar için tüketicilerinde yarattığı sinik tutumların farkında olmak bu duygular ile başa çıkmak için bütünleşik bir iletişim faaliyeti yürütmek oldukça önemlidir. Konu ile ilgili yerli alan yazında çeşitli çalışmalar yer alsa da bu çalışma ile reklam ile tüketici sinizm arasında kurulan bağ yenidir. 


\section{KAYNAKÇA}

Akcan, B., Erdoğan, M., \& Karaçor, S. (2020). Para Cuma. Selçuk Üniversitesi Sosyal Bilimler Meslek Yüksekokulu Dergisi, 43-53.

Çiçek Sepeti. (2021, Haziran 17). Çiçek Sepeti Hakkımızda. https://www.ciceksepeti.com/hakkimizda adresinden alındi.

Özbek, A. (2021, Mart 2). Kampüsten Pazarlama Analizi: Trendyol Dijital Pazarlama Faaliyetleri. https://www.amfiweb.net/kampusten-pazarlama-analizi-trendyol-dijital-pazarlamafaaliyetleri/ adresinden alındı.

Andersson, L., \& Bateman, T. (1997). Cynicism in the workplace: some causes and effects. Journal of Organizational Behavior, 449-469.

Bozoklu, Ç., \& Ermeç, A. (2020). Tüketici Sinisizmi Ölçeği'nin Türkçe'ye Uyarlanması: Güvenilirlik ve Geçerlilik Araştırması. Ankara Hacı Bayram Veli Üniversitesi İktisadi ve İdari Bilimler Fakültesi Dergisi, 440-459.

Brenton, S. (2013). The political motivations of ethical consumers. International Journal of Consumer Studies, 490-497.

Chu, A., \& Chylinski, M. (2006). M. A Model of Consumer Cynicism-Antecedents and Consequences. Proceedings of the Australian and New Zealand Marketing Academy.

Devlin, J., \& McKechnie, S. (2008). Consumer perceptions of brand architecture in financial services. European Journal of Marketing, 654-666.

Dolen, W., Cremer , D., \& Ruyter, K. (2012). Consumer cynicism toward collective buying: the interplay of others' outcomes, social value orientation, and mood. Psychology \& Marketing, 306-321.

Güven, E. (2016). Tüketimde Sinik Tutum: Tüketici Sinizminin Sebep ve Sonuçları. Journal of Business Research Turk, 152-174.

Helm, A., Moulard, J., \& Richins, M. (2015). Consumer cynicism: developing a scale to measure underlying attitudes influencing marketplace shaping and withdrawal behaviours. International Journal of Consumer Studies, 515-524.

Holt , D. (2002). Why Do Brands Cause Trouble? A Dialectical Theory of Consumer Culture and Branding. Journal of Consumer Research, 70-90.

Koslow, S. (2000). Can the truth hurt? How honest and persuasive advertising can unintentionally lead to increased consumer skepticism. Journal of Consumer Affairs, 245-269.

Nunnally, J. (1978). Psychometric theory. McGrawHill. 
Pollay, R. (1986). The distorted mirror: Reflections on the unintended consequences of advertising. Journal of Marketing, 18-36.

Taylor, S., Peplau, L., \& Sears, D. (2010). Sosyal Psikoloji. İmge Kitapevi.

Trendyol. (2021, Haziran 17). Hakkımızda. https://www.trendyol.com/hakkimizda adresinden alındı.

Wood, C. (2004). A crisis of confidence: Rebuilding the bonds of trust: State of consumer trust report. Chicago: 10th Annual Fred Newell Customer Relationship Management Conference: Yankel.

YouTube. (2020, Kasim 20). YouTube: https://www.youtube.com/watch?v=Vo8QbRxOEy0\&t=2s adresinden alındı

YouTube. (2021, Haziran 2). YouTube. https://www.youtube.com/watch?v=yzqn0z5YFDI adresinden alındi. 